\title{
Report of Apogonichthyoides sialis (Perciformes: Apogonidae) from the west coast of India
}

\author{
HASHIM MANJEBRAYAKATH, K.V. AKHILESH AND N.G.K. PILlAi \\ Central Marine Fisheries Research Institute, PB No. 1603, Ernakulam North PO, Cochin-683 018, Kerala, India
}

\begin{abstract}
The cardinal fish, Apogonichthyoides sialis, previously known from the eastern Indian Ocean and western Pacific, is reported from the south-west coast of India (Kerala coast). The specimens are described and figured.
\end{abstract}

Keywords: Apogonichthyoides sialis, distribution extension, Arabian Sea, south-western India

Submitted 22 October 2011; accepted 4 December 2011

Cardinalfish (Apogonidae) is a speciose family of marine teleosts with about 23 genera and 347 valid species, of which most occur in shallow water in tropical and subtropical marine environments and a few species occur in brackish and fresh water environments (Nelson, 2006; Fraser \& Allen, 2010). Apogonid fish are usually small in size $(<100 \mathrm{~mm}$ total length) but a few species in the genera Apogon, Holapogon, Apogonichthyoides, Cheilodipterus, Glossamia and Pseudamia grow to larger sizes (Fraser, 1973; Froese \& Pauly, 2011).

The genus Apogonichthyoides, which was resurrected from Apogon, contains 19 valid species (Fraser \& Allen, 2010). The characteristics of the genus are: body colour brown to brownish-black; head and body usually with dark (brown or black) spots which are sometimes stripe-like; a dark cheek line and usually two body bars. An ocellus may be present below the lateral line on the body; one or more bars on the caudal peduncle or a spot on the base of the caudal fin are often present (Fraser \& Allen, 2010).

Species of the 'Apogonichthyoides nigripinnis' complex have a similar colour pattern with a dark colour and a spot on the caudal peduncle. The species known from the western Indian Ocean 'A. nigripinnis' group are A. enigmaticus, A. heptastygma, A. pharaonis, A. pseudotaeniatus, $A$. taeniatus and $A$. nigripinnis from the Indo-West Pacific (Fraser \& Allen, 2010; Froese \& Pauly, 2011).

Apogonichthyoides sialis (Jordan \& Thompson, 1914), originally described as Amia sialis from Suruga Bay (Japan) is distributed from the western Pacific (including Japan, Taiwan and China) to the east coast of India (Gon, 2000). On 3 August 2011 five specimens of $A$. sialis were collected from demersal fish trawl landings at Munambam Fisheries Harbour, south-western India. The main part of the catch comprised Nemipterus randalli and N. japonicus. The morphometric and meristic characters of the specimens collected agree well with the description of Gon (2000), but a few characteristics overlapped with the present specimens which

Corresponding author:

H. Manjebrayakath

Email: hashimaqua@gmail.com were: colour variants, probably due to habitat; dark colour of the dorsal, anal and caudal fins versus paler in the living photographs of $A$. sialis. The present work extends the distribution of $A$. sialis to the west coast of India.

\section{SYSTEMATICS \\ APOGONIDAE}

Apogonichthyoides sialis (Jordan \& Thompson, 1914)

\section{MATERIALS EXAMINED}

Apogonichthyoides sialis (DNR CMFRI. GB. 31. 9. 2. 1), (5 specimens, 89.4-102.8 mm standard length), trawls, off Cochin, Kerala, India, 20-70 m depth.

\section{DIAGNOSIS}

Dorsal fin rays VII + I, 9; anal fin rays II, 8; pectoral fin rays 15-16; lateral-line scales $23-24+2-4$; predorsal scales 4 , dorsal origin to LL 3 scales. Rudiments and gill-rakers $3+2-8-9+4-6,10-11$ rakers, total 5+12-15; two dark body bars from base of each dorsal fin; small basicaudal spot.

\section{DESCRIPTION}

Proportional measurements in percentage of standard length (SL) are given (Tables 1 \& 2). A medium sized Apogon, with dark colour and very small spots and a black spot on caudal (Figure 1). Body depth $2.3-2.4$ in SL; head length (HL) 41.9-45\% SL, 2.2-2.4 in SL; snout length $4.1-4.5$ in HL; upper jaw length $19.2-19.7 \%$ SL; third dorsal-fin spine $22.3-23.6 \%$ SL; second dorsal spine $18.7-20.4 \%$ SL; pelvic-fin spine 15.6-18.0\% SL; caudal peduncle depth (CPD) $16.1-$ $17.5 \%$ SL; caudal peduncle length (CPL) 19.5-24.8\% SL, 45.6 in SL; caudal spot diameter $4.8-5.6 \%$ SL. Eye diameter 3.5-3.9; interorbital 4.2-4.7; upper jaw 2.1-2.4; third dorsal spine 1.8-2.0; second anal spine 4.6-6.1; pelvic spine 2.42.9, all in HL (Tables 1 \& 2). Preoperculum finely serrated. Pelvic bases connected by a membrane (interpelvic space 


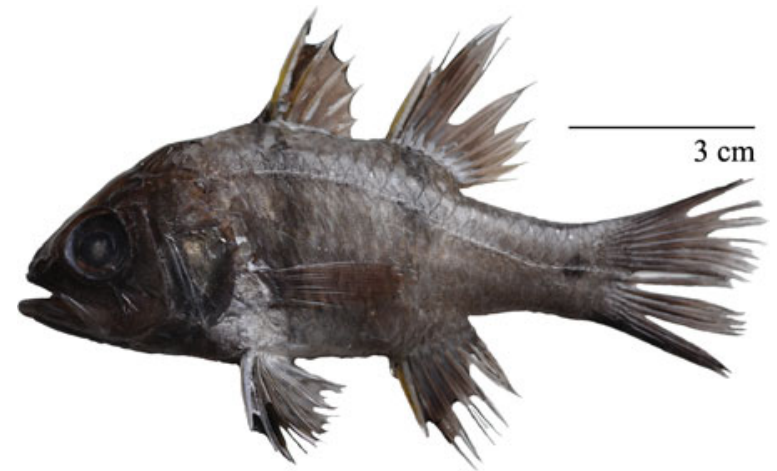

Fig. 1. Apogonichthyoides sialis, Arabian Sea, collected off Cochin, India.

covered). Large mouth, villiform teeth. Pectoral fin nearly reaches to anal fin origin in vertical. Caudal fin emarginate.

\section{COLOUR}

Colour in alcohol: body grey-brown with minute small dark spots and with two distinct dark bars, one under anterior base of each dorsal fin; intestine pale.

Colour of fresh specimens: body dark; dark bars from dorsal to ventral side, reaching to level of lower pectoral-fin base or slightly lower; a distinct dark caudal spot.

\section{REMARKS}

A similar species from western Indian Ocean, A. pseudotaeniatus (Gon, 1986) described from the Red Sea can be

Table 1. Morphometric measurements of Apogonichthyoides sialis (Jordan \& Thompson, 1914) from south-west coast of India (in \% standard length).

\begin{tabular}{lc}
\hline Characters & Range \\
\hline Total length (mm) & $115.2-133.6$ \\
Standard length (mm) & $89.4-102.8$ \\
Head length & $41.9-45.3$ \\
Body depth & $41.4-44.4$ \\
Width of the body & $17-17.9$ \\
Snout length & $10-10.7$ \\
Eye diameter & $11-12.5$ \\
Inter orbital width & $9.4-10.3$ \\
Length of upper jaw & $19.2-19.7$ \\
First dorsal fin base length & $17.4-20.1$ \\
First dorsal spine length & $2.1-4.4$ \\
Second dorsal spine length & $7.1-9.3$ \\
Longest dorsal spine length (3) & $22.3-22.6$ \\
Second dorsal fin base length & $15.5-17$ \\
Second dorsal fin spine length & $18.7-20.4$ \\
Longest dorsal ray & $21.9-31.3$ \\
Anal fin base length & $14.8-16$ \\
Anal fin length & $26.4-28.3$ \\
First anal spine length & $3.4-5.1$ \\
Second anal spine length & $15.6-16.7$ \\
Longest anal ray length & $24.2-29.8$ \\
Pectoral fin length & $25.8-28.3$ \\
Pelvic fin length & $25.6-1.5$ \\
Pelvic spine length & $19.5-24.8$ \\
Caudal peduncle length & $16.1-17.5$ \\
Depth of caudal peduncle & $44.6-48.3$ \\
Snout to first dorsal-length & $65.1-68.2$ \\
Snout to second dorsal-length & $39.2-42.3$ \\
Snout to pelvic origin-length & \\
Caudal spot diameter & \\
\hline & \\
\hline
\end{tabular}

Table 2. Ranges of measurements (in \% standard length) of five Apogonichthyoides sialis 89.4 - $102.8 \mathrm{~mm}$ (present study) and Apogonichthyoides sialis, 61.4 - $96.7 \mathrm{~mm}$ and four Apogonichthyoides pseudotaeniatus, 56.9 - $110 \mathrm{~mm}$ from Gon, 2000.

\begin{tabular}{lcll}
\hline & A. sialis & A. pseudotaeniatus & $\begin{array}{l}\text { A. sialis } \\
\text { (present study) }\end{array}$ \\
\hline Head length & $40-43$ & $42-46$ & $41.9-45.3$ \\
Upper jaw & $18-20$ & $20-22$ & $19.2-19.7$ \\
Third dorsal-fin spine & $21-27$ & $18-22$ & $22.3-23.6$ \\
Second dorsal spine & $19-23$ & $15-19$ & $18.7-20.4$ \\
Pelvic-fin spine & $18-19$ & $16-17$ & $15.6-18.0$ \\
Caudal peduncle depth & $16-19$ & $14-17$ & $16.1-17.5$ \\
Caudal peduncle length & $24-24$ & $21-23$ & $19.5-24.8$ \\
Caudal spot diameter & $3.5-6.7$ & $2.6-3.6$ & $4.8-5.6$ \\
\hline
\end{tabular}

confused with $A$. sialis in colour pattern and morphometry, except for a few characters such as: third dorsal spine 1.9-2 in HL (2.0-2.45 in A. pseudotaeniatus) and smaller dark basicaudal spot, spot diameter 3.5-5.2 in CPD (4.6-6.1 in A. pseudotaeniatus). Moreover A. pseudotaeniatus has a blackish intestine and usually $14-15$ pectoral fin rays, whereas A. sialis has a pale intestine and usually 15 pectoral fin rays.

Day's (1875) Fishes of India, plate 16 figure 9 misidentified as A. bifasciatus is A. sialis. There are no specimens of $A$. pseudotaeniatus reported from the eastern Indian coastline, but Gon (1986) suggested Day's (1875) report of A. taeniatus was $A$. pseudotaeniatus with abnormality which could be A. sialis. Apogonichthyoides pseudotaeniatus is probably restricted to the Red Sea, Arabian coast and the Persian Gulf and prefers reefs found at 5-30 m depth (Gon \& Randall, 2003), whereas present $A$. sialis specimens were collected from the south-western coast of India, 20-70 m depth. Suresh \& Thomas (2006) reported A. pseudotaeniatus from the west coast of India which also could be A. sialis. This report of $A$. sialis from the south-western coast of India indicates an extension of distribution from its known localities.

\section{ACKNDWLEDGEMENTS}

The authors are grateful to the Director, CMFRI for the support and encouragement. Our sincere thanks to Dr Thomas H. Fraser, Florida Museum of Natural History, USA, for sending valuable publications required for preparation of manuscript and all support. We would also like to thank the referee for helpful comments on the manuscript.

\section{REFERENCES}

Day F. (1875) The fishes of India, being a natural history of the fishes known to inhabit the seas and fresh waters of India, Burma and Ceylon. Part 1. London: William Dawson \& Sons Ltd., 168 pp.

Fraser T.H. (1973) Evolutionary significance of Holapogon, a new genus of cardinal fishes (Apogonidae), with a redescription of its type species, Apogon maximus. Special Publications. J.L.B. Smith Institute of Ichthyology, Rhodes University 10, 1-7.

Fraser T.H. and Allen G.R. (2010) Cardinalfish of the genus Apogonichthyoides Smith, 1949 (Apogonidae) with a description of a new species from the West-Pacific region. Zootaxa 2348, 40-56. 
Froese R. and Pauly D. (eds) (2011) FishBase. World Wide Web electronic publication. (Version 10/2011.) www.fishbase.org.

Gon O. (1986) Apogon bifasciatus Rüppell 1838, junior synonym of Apogon taeniatus Ehrenberg, 1828, and description of Apogon pseudotaeniatus n. sp. (Pisces: Apogonidae). Senckenbergiana Biologica 67, 5-17.

Gon O. (2000) The taxonomic status of the cardinalfish species Apogon niger, A. nigripinnis, A. pharaonis, A. sialis, and related species (Perciformes: Apogonidae). Special Publications, J.L.B. Smith Institute of Ichthyology, Rhodes University 65, 1-20.

Gon O. and Randall J.E. (2003) A review of the cardinalfishes (Perciformes: Apogonidae) of the Red Sea. Smithiana Bulletin 1, 1-46.

Jordan D.S. and Thompson W.F. (1914) Record of the fishes obtained in Japan in 1911. Memoirs of the Carnegie Museum 6, 205-313.
Nelson J.S. (2006) Fishes of the world. 4th edition. Hoboken, NJ: John Wiley \& Sons, Inc., 624 pp.

and

Suresh G.K. and Thomas P.A. (2006) On three new records of apogonids (Order-Perciformes, Suborder-Percoidei) from the Indian seas. Journal of the Marine Biological Association of India 48, 83-88.

\section{Correspondence should be addressed to:}

H. Manjebrayakath

Central Marine Fisheries Research Institute

PB No. 1603, Ernakulam North PO

Cochin-683 018, Kerala

India

email: hashimaqua@gmail.com 